\title{
The value of IGF 1 estimation in adults with GH deficiency
}

\author{
A Mukherjee and S M Shalet ${ }^{1}$ \\ Department of Endocrinology, Salford Royal NHS Foundation Trust, Stott Lane, Salford, M6 8HD, UK and ${ }^{1}$ Christie Hospital NHS Foundation Trust, \\ Manchester, M20 4BX, UK \\ (Correspondence should be addressed to A Mukherjee; Email: annice.mukherjee@srft.nhs.uk)
}

\begin{abstract}
The GH/IGF1 system, like other endocrine systems, is dynamic and its activity changes with age and sexual maturation, and is influenced by body composition and other factors. A normal level of IGF1 does not exclude a diagnosis of GH deficiency (GHD) in adults, and the usefulness of IGF1 in the diagnosis of adult GHD has historically been confusing and contentious. The regulation of IGF1 secretion in adults is complex, and is not solely dependent on GH status with factors recognized to influence IGF1 status in patients with GHD including age, gender, exogenous estrogen therapy, prolactin status, and severity of GHD. The usefulness of IGF1 for monitoring treatment of GH disorders in adulthood is now widely accepted, especially as GH-dosing regimens for GHD have evolved from weight-based dosing (associated with overtreatment and side effects) to individualized dose-titration strategies, which maintain IGF1 within target limits. Sub-optimal replacement therapy may be associated with morbidity and mortality risk from a continuing state of functional GHD. Conversely, avoiding iatrogenic biochemical acromegaly is clearly important and other potential safety issues may be associated with a persistently high IGF1. Analysis and interpretation of IGF1 status therefore represent a useful diagnostic tool especially in the younger adult patients with severe GHD and an essential measurement for monitoring GH replacement in all adults with GHD. High-quality, methodspecific reference ranges for IGF1 and a high degree of methodological consistency in the assay are essential for reliable comparison of results.
\end{abstract}

European Journal of Endocrinology 161 S33-S39

\section{Introduction}

The importance of GH for longitudinal growth in childhood has been widely recognized since the middle of the 20th century, but its physiological effects in adults were not widely considered until the introduction of recombinant human GH (1), which became widely available in the middle of the 1980s and provided an opportunity for more detailed study of the effects of $\mathrm{GH}$ in adults.

In adult life, physiologically, GH acts both directly through its own receptor and indirectly through the induced production of insulin-like growth factor 1 (IGF1). IGF1 is synthesized both in the liver and in the periphery, and is an important mediator of GH actions. It circulates bound to a number of different proteins of which IGF-binding protein-3 (IGFBP-3) is the most important. The changes in IGF1 levels throughout life are similar to those of GH. With the onset of puberty, there is a two- to three-fold rise in serum IGF 1 concentration followed by a decline such that

This paper forms part of a special issue on $\mathrm{KIMS}^{\circledR}$ and ACROSTUDY $^{\mathrm{TM}}$. Pfizer Inc. has supported the publication of this special issue. average adult levels are reached by the early twenties, and thereafter follows a gradual decline with advancing age (2). Thus, in the adult patient investigated for possible GH deficiency (GHD), serum IGF1 measurements can only be interpreted if decade-based normative data are available.

The existence of GHD as a discrete clinical entity in adults became widely recognized 20 years ago $(3,4)$. In adult life, GHD is associated with wide-varying biological features, which consist of adverse metabolic parameters, abnormal body composition, an adverse cardiovascular risk profile, reduced bone mineral density (BMD), and impairment in quality of life (QOL) (5). However, unlike GHD in childhood in which growth velocity represents a single objective and widely used diagnostic biological marker, in adult GHD there is no single biological marker able to offer similar diagnostic usefulness.

It is apparent that the GH/IGF1 system, like other endocrine systems, is a dynamic one, the activity of which changes with age and sexual maturation, and is influenced by body composition and other factors. Clearly, it is not possible to recreate normal physiology with a single, daily s.c. injection of $\mathrm{GH}$, so the general goal of treatment of GHD is correction of the associated clinical syndrome within appropriate safety limits. 


\section{Diagnosis of GHD}

GH is secreted in an episodic manner, which is modified by age and sex. Because of this pulsatile secretion, a series of multiple $\mathrm{GH}$ samples over $24 \mathrm{~h}$ most accurately reflect GH status, but this is not practical as a diagnostic procedure in clinical practice. For this reason, current diagnostic testing generally involves provocative tests of GH secretion, although some of these tests have reduced specificity and others have safety issues under some circumstances (6).

In adult patients with known pituitary disease, the presence and severity of GHD are related to the number of additional pituitary hormone deficits $(7,8)$. Several studies involving panhypopituitary patients have shown that under certain circumstances, GH stimulation tests may be unnecessary to diagnose adult GHD $(7,9,10)$.

Having normal levels of IGF1 and IGFBP-3 does not exclude a diagnosis of GHD in adults $(9,11-13)$. Because of this observation, the perceived role of IGF1 estimation in the diagnosis of adult GHD has been confusing and contentious. Indeed, the regulation of IGF1 secretion in adults is complex and is not solely dependent on GH status. A considerable overlap exists for IGF1 levels between normal subjects and those with GHD (12, 14-17). This overlap remains apparent even among patients with the most severe degree of GHD identified by provocative tests of GH secretion or the number of additional pituitary hormone deficits (17). Therefore, although IGF1 levels may be reduced in patients with GHD, IGF1 has not widely been viewed as a reliable marker for the diagnosis of GHD. However, IGF1 can be of some diagnostic assistance if levels are below the age-adjusted normal range and if factors known to lower IGF1 levels, such as liver disease (18) and starvation (19), are taken into consideration.

Recognized factors influencing IGF1 status in GHD patients include age (20), gender $(13,21-26)$, exogenous estrogen therapy (27), and prolactin status (28).

At least some of the disparity between studies of IGF1 levels in GHD adults is explained by the timing of the onset of GHD. In an early study, Hoffman et al. (12) found that $70 \%$ of IGF1 values in adult-onset GHD patients, mean age 45 years, were within the range of normal subjects even allowing for the effects of age. DeBoer et al. (29) focused on childhood-onset GHD and re-evaluated GH status in 89 young adult males who had previously received GH replacement in childhood. Approximately $93 \%$ of the patients had an IGF1 level below the normal range. Attanasio et al. pursued the same theme in a study of 74 childhood-onset and 99 adult-onset GHD patients, and concluded that there are profound differences between these two forms of GHD with serum IGF1 levels significantly lower in childhoodonset than adult-onset GHD patients (30). In these studies, however, it was not clear whether sufficient decade-based normative data were available or whether the severity of GHD was equal in the childhood-onset and adult-onset groups. Thus, apart from the potential impact of the timing of onset of GHD, it is possible that the severity of GHD influenced the interpretation of IGF1 results. Lissett et al. subsequently studied age-adjusted IGF 1 SDS in a large cohort of GHD adults from the KIMS database to investigate determinants of IGF1 status and in particular to examine whether a true difference existed between subjects who developed GHD in adult life (AO), and those who developed GHD in childhood (CO) (31). In this study, 1317 patients (1073 with AO GHD and 244 with CO GHD) were included. A total of $86 \%$ of patients were with CO GHD, but only $52 \%$ of patients with AO GHD had IGF1 SDS below - 2 SDS. The CO cohort had a significantly lower IGF1 SDS $(-4.69$ vs $-2.24, P<0.0001)$ and a smaller body mass index (BMI; $26.6 \mathrm{vs} 28.6 \mathrm{~kg} / \mathrm{m}^{2}, P<0.0001$ ) than the AO cohort. In a stepwise multiple linear regression, age at onset of GHD was the most important determinant of IGF1 SDS, contributing 17\% towards the variability of IGF1 SDS. Timing of onset, gender, BMI and number of pituitary hormone deficiencies other than GHD were also significant determinants of IGF1 SDS. This study demonstrated that age at onset of GHD was the most important determinant of IGF1 SDS, individuals with CO GHD had IGF1 values on average 1.43 SDS lower than those with AO GHD, all other factors being equal (31).

In line with the previous observations, IGF1 estimation therefore appears to offer relatively little diagnostic value in the elderly with suspected GHD. Despite group differences, overlap between patients over age 60 years with organic GHD and controls is considerable, with only $21 \%$ of elderly GH-deficient patients having a serum IGF1 level below the range found in the elderly controls (15).

In one study, the presence of three or more other deficits, together with a below normal serum IGF1 level, was demonstrated to be a predictor as specific as the $\mathrm{GH}$ provocative tests employed (9). It has been recommended that in this specific context, it is reasonable to omit GH provocative tests, provided that nonGHDrelated causes of a low IGF1 have been excluded (6).

\section{Dosing schedules and monitoring}

Although IGF1 has not been considered as a systematically reliable marker for the diagnosis of GHD, its usefulness for monitoring $\mathrm{GH}$ replacement in adult patients with GHD is now widely accepted. For this purpose, the literature to date suggests that IGF1 is a better marker than IGFBP-3 or the acid-labile subunit (32). In untreated GHD adults, basal IGF1 levels are lower in females than in males (13). The therapeutic $\mathrm{GH}$ dose required to achieve target IGF1 levels is higher in females, suggesting a pivotal role of estrogens 
on GH requirement in GH-deficient adults (22). Furthermore, the route of administration of estrogen is a determinant of IGF1 levels in hypogonadal GHD females, and higher IGF1 levels are achieved at lower GH dosing in women treated with transdermal estrogens $(33,34)$.

The potential improvement of several adverse features of the adult GHD syndrome with GH therapy means that changes in these endpoints can be used as clinical indicators of GH efficacy during replacement therapy.

During the initial double-blind placebo-controlled trials of $\mathrm{GH}$ replacement, and in the immediate period after its license for use in adults, it was thought, by analogy with pediatric practice, that clinical monitoring would be sufficient and that markers such as body composition would simply substitute for linear growth. Early GH dosing in adults was therefore adopted arbitrarily from pediatric practice with fixed dose regimens, but this approach caused high rates of adverse effects associated with pathologically elevated IGF1 levels. Subsequent data demonstrated that adults are generally much more susceptible to the side effects of GH excess than children, even at doses achieving similar IGF1 responses $(24,35,36)$.

With time and shared clinical experience, from a combination of placebo-controlled studies (both single and multicenter) and information collected through international outcomes-based multicenter research databases, it became apparent that individual responsiveness to GH is highly variable and that the dose needs to be adjusted to suit each individual patient. This, in turn, is accomplished using a combination of tolerability (i.e. the occurrence of side effects), clinical response, and measurement of biochemical indices of $\mathrm{GH}$ action.

Dosing regimens subsequently evolved from weightbased dosing to individualized dose-titration strategies. Two studies that formally compared these dosing approaches found that adverse effects were less than half as frequent in the dose-titration group as in the weight-based dosing group, and the final maintenance doses were somewhat lower in the dose-titration group than in the weight-based dosing group $(36,37)$. A recent study has clarified this by producing 10-year demographic, efficacy, and safety data for GH-replaced GHD adults (38). This study spanned through the two different dosing regimens with dosing based primarily on weight at the beginning of the study, but this evolved exclusively into dose-titration by the end of data collection. The mean GH dose was reduced during the time of data collection to less than half the original dose (0.98-0.47 mg/day), but the mean IGF1 level remained significantly higher, within physiological limits, than baseline (38). This study clearly demonstrated the change in practice over time with a current focus on individualized dosing using IGF1 monitoring as the primary biochemical safety check.

\section{Optimization}

During GH replacement therapy in adults with GHD, IGF1 monitoring is now therefore used to aid dosetitration, in order to minimize the risk of overtreatment. However, targeting IGF1 levels broadly to within the normal age-related reference range during treatment of GHD in adults does not preclude the presence of a functional GHD state with, in effect, relative underreplacement for that individual. Therefore, careful consideration of factors influencing IGF1 levels in adults is crucially important in order to interpret IGF1 levels, infer GH status appropriately, and ultimately provide the adult GHD patient with the best possible approach to management. The relationship between IGF1 and GH in adults is complex, and IGF1 levels are not solely dependent on GH. A wide variation in IGF1 levels occurs with age and gender in healthy adults (39). A large overlap exists for IGF1 levels between patients with severe AO GHD and normal subjects (13). Discordance of IGF1 SDS exists between GHD males and females of similar ages $(13,17,21-26)$, but this is notably different from the situation in normal adults (40-43). The relationship between GH and IGF1 in normal adults is influenced by gender, which may be explained partly by a difference in GH-secretory dynamics (42). It has been demonstrated that at similar IGF1 levels, females secrete three times more GH than males (42). As normal GH secretory physiology differs between genders, a paradox is apparent as GHD diagnostic criteria are not gender specific. Similarly, the widely accepted diagnostic threshold for GHD after provocation testing does not take account of increasing age. It may be inferred that diagnostic criteria for GHD may be more 'strict' in females and young adults, and more 'lenient' in males and the elderly, which may be a contributory factor to the difference in IGF1 levels between these groups. Currently, however, it is not possible to deduce for which of these groups the GHD diagnostic criteria are most biologically appropriate. In a large study by Brabant et al. the GH peak during insulin tolerance test (ITT) was positively related to IGF1 level suggesting that GHD patients with low IGF1 levels have more severe GHD than those with normal IGF1 levels (44). This proposition has therapeutic implications and has also been suggested by others (28).

The factors discussed above all contribute to and illustrate the complexity of interpretation of IGF1 levels in adult GHD, and iterate the fact that optimization of $\mathrm{GH}$ replacement in adults is by no means a straightforward concept. Nonetheless, the importance of the generation of a framework to enable safe and logical targeting of IGF1 levels during the treatment of adult GHD should not be underestimated; sub-optimal replacement therapy may be associated with unresolved morbidity and increased mortality risk from a continuing state of functional GHD. In an attempt to investigate and quantify this risk, a novel study utilized baseline 
IGF1 data from the KIMS database (17). This large study included only GHD adults with three or more anterior pituitary hormone deficits (including GHD), therefore reflecting the most severe GHD adults (15). It stratified IGF1 values by age and gender in decade-based age ranges, and demonstrated that age- and genderrelated IGF1 SDS upper percentiles in GHD patients were almost exclusively limited to the lower half of the normal age-related range. The study highlighted a range of IGF1 values that were higher than those found in untreated GHD with high sensitivity (Fig. 1) (17), while underlining the need for interpretation of IGF1 SDS based on the factors discussed above. These data were proposed for use during GH dose-titration for GHD patients who do not respond clinically to a conventional therapeutic trial of $\mathrm{GH}$ replacement, especially if the IGF1 level has remained below the 95th percentile for functional GHD and could equally be used conversely during treatment of acromegaly with a $\mathrm{GH}$ receptor antagonist when $\mathrm{GH}$ levels are also uninterpretable (17). These data may be considered even more important in light of a recent study demonstrating an association between low IGF1 levels and increased all cause and cardiovascular mortality in general populations (45).

\section{Safety}

The relatively recent advent of unlimited supplies of recombinant human $\mathrm{GH}$ and its use for the treatment of $\mathrm{AO} \mathrm{GHD}$ means that long-term outcome data regarding the effects of an elevated level of serum IGF1 in hypopituitarism are not yet available, although the large databases permit the identification of subtle trends regarding individual susceptibility, together with early detection of important safety issues that may not be possible from a single center or even a single country (46).

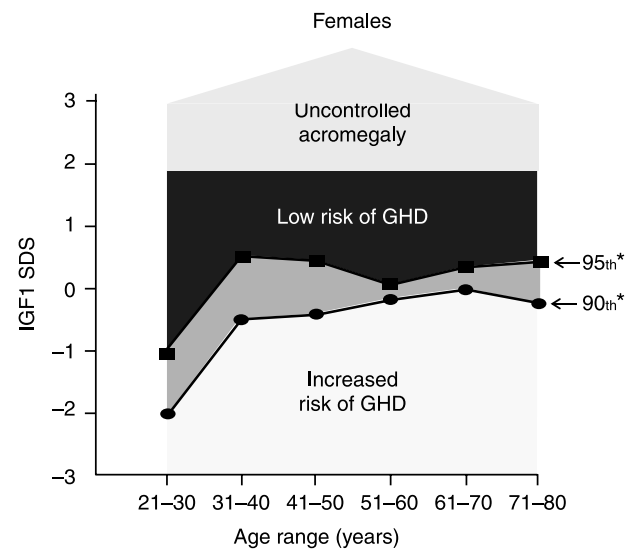

In the absence of such outcome information, indirect evidence must be extrapolated from clinical experience in the treatment of acromegaly, a condition known to be associated with excess morbidity and mortality (47), chiefly from cardiovascular causes and presumed to be on account of the associated insulin resistance, hypertension, and characteristic cardiomyopathy. The argument for the avoidance of pharmacological doses of GH would appear strong. Recent reports, both from a single center and from an international study, of the effect of more physiological doses of GH in hypopituitary adults are reassuring $(48,49)$.

Avoiding iatrogenic biochemical acromegaly is clearly important, but other potential safety issues exist. Considerable epidemiological data have suggested a possible link between circulating $\mathrm{GH}$ and/or IGF1 levels and the development of a variety of different cancers in the general population.

Multiple studies have now shown that within a normal population, high-normal rather than lownormal levels of IGF1 identify people at higher risk of subsequently developing breast, prostate, and colon cancer (50-52). In these studies, high-normal levels of serum or plasma IGF1 with low-normal levels of IGFBP-3 identified subjects at higher risk of developing cancer.

A systematic review and meta-regression analysis were carried out to identify epidemiological casecontrol studies, including studies nested in cohorts, investigating the association between concentrations of IGF1 and IGFBP-3 and prostate, colorectal, premenopausal and postmenopausal breast, and lung cancer (53). The studies included in this analysis had to be published as full-article findings expressed as odds ratios with 95\% confidence interval, CI, and had to report an association for at least three categories of peptide concentration. Methodological quality was assessed by the use of published criteria for observational studies. Out of 139 relevant publications identified, 21 studies (26 datasets) comprised of 3609 cases and

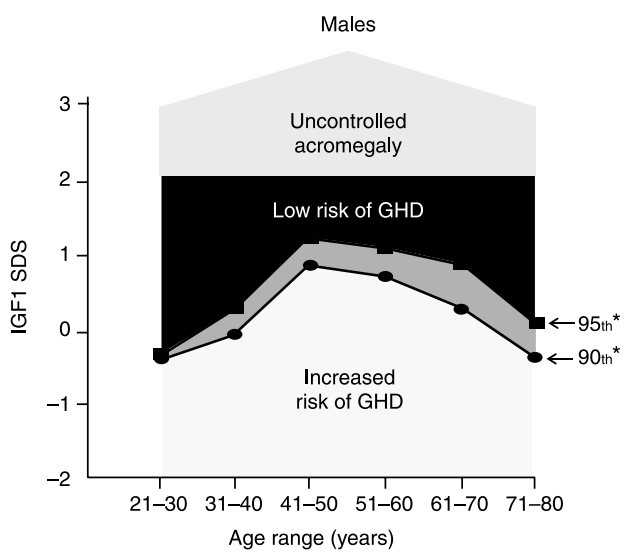

Figure 1 Age-related IGF1 SDS 90 and 95th percentiles for GHD in (a) females and (b) males illustrated as a 'GHD risk estimate plot', which may aid dose-titration of treatment during the management of GH disorders in adulthood. *Denotes percentiles. 
7137 controls had outcome data appropriate for inclusion in the meta-analysis.

High-normal concentrations of IGF1 were associated with a twofold increased risk in prostate cancer $(P=0.009)$, colorectal cancer $(P=0.09)$, and premenopausal breast cancer $(P=0.007)$, but not postmenopausal breast cancer or lung cancer. IGFBP-3 was associated positively with an increased risk in premenopausal breast cancer $(P=0.05)$.

Mutual adjustment for IGF1 and IGFBP-3 did not appear to affect results. Previous narrative reviews have tended to highlight positive associations with IGF1 and inverse associations with IGFBP-3 and quote three- to four-fold increases in cancer risk. The authors of the systematic review and meta-regression analysis of overall cancer risk suggest that the increased cancer risk is real, but the extent has been exaggerated (53).

\section{Assays}

Analysis and interpretation of IGF1 levels therefore represent a useful diagnostic tool and an essential follow-up tool in GHD and other GH-related disorders.

Immunoassays that measure circulating concentrations of IGF1 are widely used for monitoring during $\mathrm{GH}$ replacement and increasingly used to diagnose GHD in conjunction with other parameters. While techniques for measuring IGF1 have evolved over the decades, immunoassays are still the primary tool used in routine laboratories. Immunoassays depend on the interaction between antibodies and the analyte, and all factors that modify the accessibility of the epitopes recognized by the antibodies can influence results. With IGF1 assays, interference from binding proteins is an important variable affecting assay results. It is generally accepted that assay- and age-specific reference ranges are mandatory for meaningful interpretation of IGF1 concentrations.

Age- and sex-specific reference values based on a large population and valid for different laboratories were established by Brabant et al. for the automated chemiluminescence immunoassay Nichols Advantage in 2003 (39). Later data have shown that reference values established for the chemiluminescence assay are also applicable for the ELISA (DSL-10-2800) (54). However, although the precision of IGF1 assays has improved over the last decade, the lack of standardization of IGF1 assay methodology remains a limitation $(55,56)$.

The large inter- and intra-assay variation in IGF1 remains a problem and limits the applicability of international consensus criteria to local practice. Furthermore, high-quality, method-specific reference ranges and a high degree of methodological consistency in the assay are essential for reliable comparison of results across studies and for long-term monitoring of individual patients. Established reference values can only be used for assay results from different laboratories, provided that the systematic difference between assay systems is low. In practice, individual reference values are desirable as this is not often the case.

\section{Summary and future direction}

Analysis and interpretation of IGF1 have emerged as a useful diagnostic tool and an essential follow-up tool for the management of adults with GHD. It is also important in the context of monitoring treatment for acromegaly $(17,57,58)$. An association between high IGF1 levels and cancer risk appears genuine (53), and the ability of IGF1 levels to favor survival of genetically damaged cells is clear-cut (59). Recent data have suggested that low IGF1 levels in the context of GHD and normal populations are associated with increased vascular risk and adverse cardiovascular and cancer mortality (45). The compelling need for careful interpretation of IGF1 data and the requirement for optimization of IGF1 status emphasize the greater importance of robust and reliable IGF1 assays and targeting IGF1 levels during GH replacement and other GH disorders appropriately (17).

\section{Declaration of interest}

The authors disclose no potential conflicting relationship with Pfizer. KIMS $^{\circledR}$ is supported by Pfizer Inc. This paper forms part of a European Journal of Endocrinology supplement, supported by Pfizer Inc.

\section{Funding}

This research did not receive any specific grant from any funding agency in the public, commercial, or not-for-profit sector.

\section{References}

1 Olson KC, Fenno J, Lin N, Harkins RN, Snider C, Kohr WH, Ross MJ, Fodge D, Prender G \& Stebbing N. Purified human growth hormone from E.coli is biologically active. Nature 1981293 408-411.

2 Juul A, Bang P, Hertel NT, Main K, Dalgaard P, Jorgensen K, Muller J, Hall K \& Skakkebaek NE. Serum insulin-like growth factor-I in 1030 healthy children, adolescents, and adults: relation to age, sex, stage of puberty, testicular size, and body mass index. Journal of Clinical Endocrinology and Metabolism $1994 \mathbf{7 8} 744-752$.

3 Salomon F, Cuneo RC, Hesp R \& Sonksen PH. The effects of treatment with recombinant human growth hormone on body composition and metabolism in adults with growth hormone deficiency. New England Journal of Medicine 1989321 1797-1803.

4 Jorgensen JO, Pedersen SA, Thuesen L, Jorgensen J, IngemannHansen T, Skakkebaek NE \& Christiansen JS. Beneficial effects of growth hormone treatment in GH-deficient adults. Lancet 19891 1221-1225.

5 Carroll PV, Christ ER, Bengtsson BA, Carlsson L, Christiansen JS, Clemmons D, Hintz R, Ho K, Laron Z, Sizonenko P, Sonksen PH, Tanaka T \& Thorne M. Growth hormone deficiency in adulthood and the effects of growth hormone replacement: a review. Growth Hormone Research Society Scientific Committee. Journal of Clinical Endocrinology and Metabolism 199883 382-395. 
6 Molitch ME, Clemmons DR, Malozowski S, Merriam GR, Shalet SM, Vance ML \& Stephens PA. Evaluation and treatment of adult growth hormone deficiency: an Endocrine Society Clinical Practice Guideline. Journal of Clinical Endocrinology and Metabolism 200691 1621-1634.

7 Toogood AA, Beardwell CG \& Shalet SM. The severity of growth hormone deficiency in adults with pituitary disease is related to the degree of hypopituitarism. Clinical Endocrinology $1994 \mathbf{4 1}$ 511-516.

8 Weissberger AJ, Verikiou K \& Sonksen PH. Diagnoses of growth hormone deficiency in adults. Lancet $1994 \mathbf{3 4 4} 483$.

9 Hartman ML, Crowe BJ, Biller BM, Ho KK, Clemmons DR \& Chipman JJ. Which patients do not require a GH stimulation test for the diagnosis of adult GH deficiency? Journal of Clinical Endocrinology and Metabolism 200287 477-485.

10 Juul A, Kastrup KW, Pedersen SA \& Skakkebaek NE. Growth hormone $(\mathrm{GH})$ provocative retesting of 108 young adults with childhood-onset GH deficiency and the diagnostic value of insulinlike growth factor I (IGF-I) and IGF-binding protein-3. Journal of Clinical Endocrinology and Metabolism 199782 1195-1201.

11 Biller BM, Samuels MH, Zagar A, Cook DM, Arafah BM, Bonert V, Stavrou S, Kleinberg DL, Chipman JJ \& Hartman ML. Sensitivity and specificity of six tests for the diagnosis of adult $\mathrm{GH}$ deficiency. Journal of Clinical Endocrinology and Metabolism $2002 \mathbf{8 7}$ 2067-2079.

12 Hoffman DM, O'Sullivan AJ, Baxter RC \& Ho KK. Diagnosis of growth-hormone deficiency in adults. Lancet $19943 \mathbf{3 4 3}$ 1064-1068.

13 Hilding A, Hall K, Wivall-Helleryd IL, Saaf M, Melin AL \& Thoren M. Serum levels of insulin-like growth factor I in 152 patients with growth hormone deficiency, aged 19-82 years, in relation to those in healthy subjects. Journal of Clinical Endocrinology and Metabolism 199984 2013-2019.

14 Juul A, Holm K, Kastrup KW, Pedersen SA, Michaelsen KF, Scheike T, Rasmussen S, Muller J \& Skakkebaek NE. Free insulinlike growth factor I serum levels in 1430 healthy children and adults, and its diagnostic value in patients suspected of growth hormone deficiency. Journal of Clinical Endocrinology and Metabolism 199782 2497-2502.

15 Shalet SM, Toogood A, Rahim A \& Brennan BM. The diagnosis of growth hormone deficiency in children and adults. Endocrine Reviews 199819 203-223.

16 Marzullo P, Di Somma C, Pratt KL, Khosravi J, Diamandis A, Lombardi G, Colao A \& Rosenfeld RG. Usefulness of different biochemical markers of the insulin-like growth factor (IGF) family in diagnosing growth hormone excess and deficiency in adults. Journal of Clinical Endocrinology and Metabolism $2001 \mathbf{8 6}$ 3001-3008.

17 Mukherjee A, Monson JP, Jonsson PJ, Trainer PJ \& Shalet SM. Seeking the optimal target range for insulin-like growth factor I during the treatment of adult growth hormone disorders. Journal of Clinical Endocrinology and Metabolism $2003 \mathbf{8 8}$ 5865-5870.

18 Holt RI, Jones JS, Stone NM, Baker AJ \& Miell JP. Sequential changes in insulin-like growth factor I (IGF-I) and IGF-binding proteins in children with end-stage liver disease before and after successful orthotopic liver transplantation. Journal of Clinical Endocrinology and Metabolism 199681 160-168.

19 Gianotti L, Lanfranco F, Ramunni J, Destefanis S, Ghigo E \& Arvat E. GH/IGF-I axis in anorexia nervosa. Eating and Weight Disorders 20027 94-105.

20 Hall K, Hilding A \& Thoren M. Determinants of circulating insulin-like growth factor-I. Journal of Endocrinological Investigation 199922 48-57.

21 Janssen YJ, Frolich M \& Roelfsema F. A low starting dose of genotropin in growth hormone-deficient adults. Journal of Clinical Endocrinology and Metabolism 199782 129-135.

22 Burman P, Johansson AG, Siegbahn A, Vessby B \& Karlsson FA. Growth hormone (GH)-deficient men are more responsive to GH replacement therapy than women. Journal of Clinical Endocrinology and Metabolism 199782 550-555.
23 Svensson J, Johannsson G \& Bengtsson BA. Insulin-like growth factor-I in growth hormone-deficient adults: relationship to population-based normal values, body composition and insulin tolerance test. Clinical Endocrinology $1997 \mathbf{4 6} 579-586$.

24 Drake WM, Coyte D, Camacho-Hubner C, Jivanji NM, Kaltsas G, Wood DF, Trainer PJ, Grossman AB, Besser GM \& Monson JP. Optimizing growth hormone replacement therapy by dose titration in hypopituitary adults. Journal of Clinical Endocrinology and Metabolism $1998 \mathbf{8 3} 3913-3919$.

25 Span JP, Pieters GF, Sweep CG, Hermus AR \& Smals AG. Gender difference in insulin-like growth factor I response to growth hormone $(\mathrm{GH})$ treatment in GH-deficient adults: role of sex hormone replacement. Journal of Clinical Endocrinology and Metabolism 200085 1121-1125.

26 Murray RD, Howell SJ, Lissett CA \& Shalet SM. Pre-treatment IGF-I level is the major determinant of GH dosage in adult GH deficiency. Clinical Endocrinology 200052 537-542.

27 Jorgensen JO, Christensen JJ, Krag M, Fisker S, Ovesen P \& Christiansen JS. Serum insulin-like growth factor I levels in growth hormone-deficient adults: influence of sex steroids. Hormone Research 200462 73-76.

28 Mukherjee A, Ryder WD, Jostel A \& Shalet SM. Prolactin deficiency is independently associated with reduced insulin-like growth factor I status in severely growth hormone-deficient adults. Journal of Clinical Endocrinology and Metabolism 200691 2520-2525.

29 De Boer H, Blok GJ \& Van Der Veen EA. Clinical aspects of growth hormone deficiency in adults. Endocrine Reviews 1995 16 63-86.

30 Attanasio AF, Lamberts SW, Matranga AM, Birkett MA, Bates PC, Valk NK, Hilsted J, Bengtsson BA \& Strasburger CJ. Adult growth hormone (GH)-deficient patients demonstrate heterogeneity between childhood onset and adult onset before and during human GH treatment. Adult Growth Hormone Deficiency Study Group. Journal of Clinical Endocrinology and Metabolism $1997 \mathbf{8 2}$ $82-88$.

31 Lissett CA, Jonsson P, Monson JP \& Shalet SM. Determinants of IGF-I status in a large cohort of growth hormone-deficient (GHD) subjects: the role of timing of onset of GHD. Clinical Endocrinology $200359773-778$.

32 Drake WM, Howell SJ, Monson JP \& Shalet SM. Optimizing GH therapy in adults and children. Endocrine Reviews 200122 425-450.

33 Janssen YJ, Helmerhorst F, Frolich M \& Roelfsema F. A switch from oral ( $2 \mathrm{mg} /$ day) to transdermal (50 microg/day) 17beta-estradiol therapy increases serum insulin-like growth factor-I levels in recombinant human growth hormone $(\mathrm{GH})$-substituted women with GH deficiency. Journal of Clinical Endocrinology and Metabolism 200085 464-467.

34 Van Der Klaauw AA, Biermasz NR, Zelissen PM, Pereira AM, Lentjes EG, Smit JW, Van Thiel SW, Romijn JA \& Roelfsema F. Administration route-dependent effects of estrogens on IGF-I levels during fixed $\mathrm{GH}$ replacement in women with hypopituitarism. European Journal of Endocrinology 2007 157 709-716.

35 Murray RD \& Shalet SM. Adult growth hormone replacement: lessons learned and future direction. Journal of Clinical Endocrinology and Metabolism 200287 4427-4428.

36 Johannsson G, Rosen T \& Bengtsson BA. Individualized dose titration of growth hormone $(\mathrm{GH})$ during $\mathrm{GH}$ replacement in hypopituitary adults. Clinical Endocrinology 199747 571-581.

37 Hoffman AR, Strasburger CJ, Zagar A, Blum WF, Kehely A \& Hartman ML. Efficacy and tolerability of an individualized dosing regimen for adult growth hormone replacement therapy in comparison with fixed body weight-based dosing. Journal of Clinical Endocrinology and Metabolism 200489 3224-3233.

38 Gotherstrom G, Bengtsson BA, Bosaeus I, Johannsson G \& Svensson J. A 10-year, prospective study of the metabolic effects of growth hormone replacement in adults. Journal of Clinical Endocrinology and Metabolism 200792 1442-1445.

39 Brabant G, Von Zur Muhlen A, Wuster C, Ranke MB, Kratzsch J, Kiess W, Ketelslegers JM, Wilhelmsen L, Hulthen L, Saller B, 
Mattsson A, Wilde J, Schemer R \& Kann P. Serum insulin-like growth factor I reference values for an automated chemiluminescence immunoassay system: results from a multicenter study. Hormone Research 200360 53-60.

40 Ho KY, Evans WS, Blizzard RM, Veldhuis JD, Merriam GR, Samojlik E, Furlanetto R, Rogol AD, Kaiser DL \& Thorner MO. Effects of sex and age on the 24-hour profile of growth hormone secretion in man: importance of endogenous estradiol concentrations. Journal of Clinical Endocrinology and Metabolism 1987 64 51-58.

41 Winer LM, Shaw MA \& Baumann G. Basal plasma growth hormone levels in man: new evidence for rhythmicity of growth hormone secretion. Journal of Clinical Endocrinology and Metabolism 199070 1678-1686.

42 Van Den Berg G, Veldhuis JD, Frolich M \& Roelfsema F. An amplitude-specific divergence in the pulsatile mode of growth hormone $(\mathrm{GH})$ secretion underlies the gender difference in mean $\mathrm{GH}$ concentrations in men and premenopausal women. Journal of Clinical Endocrinology and Metabolism 199681 2460-2467.

43 Landin-Wilhelmsen K, Wilhelmsen L, Lappas G, Rosen T, Lindstedt G, Lundberg PA \& Bengtsson BA. Serum insulin-like growth factor I in a random population sample of men and women: relation to age, sex, smoking habits, coffee consumption and physical activity, blood pressure and concentrations of plasma lipids, fibrinogen, parathyroid hormone and osteocalcin. Clinical Endocrinology 199441 351-357.

44 Brabant G, Krogh Rasmussen A, Biller BM, Buchfelder M, FeldtRasmussen U, Forssmann K, Jonsson B, Koltowska-Haggstrom M, Maiter D, Saller B \& Toogood A. Clinical implications of residual growth hormone $(\mathrm{GH})$ response to provocative testing in adults with severe GH deficiency. Journal of Clinical Endocrinology and Metabolism 200792 2604-2609.

45 Friedrich N, Haring R, Nauck M, Ludemann J, Rosskopf D, SpilckeLiss E, Felix SB, Dorr M, Brabant G, Volzke H \& Wallaschofski H. Mortality and serum insulin-like growth factor I and insulin-like growth factor binding protein 3 concentrations. Journal of Clinical Endocrinology and Metabolism 200994 1732-1739.

46 Monson JP. Long-term experience with GH replacement therapy: efficacy and safety. European Journal of Endocrinology $2003 \mathbf{1 4 8}$ S009-S014.

47 Bates AS, Van't Hoff W, Jones JM \& Clayton RN. An audit of outcome of treatment in acromegaly. Quarterly Journal of Medicine $199386293-299$.

48 Abs R, Bengtsson BA, Hernberg-Stahl E, Monson JP, Tauber JP, Wilton P \& Wuster C. GH replacement in 1034 growth hormone deficient hypopituitary adults: demographic and clinical characteristics, dosing and safety. Clinical Endocrinology 199950 703-713.
49 Florakis D, Hung V, Kaltsas G, Coyte D, Jenkins PJ, Chew SL, Grossman AB, Besser GM \& Monson JP. Sustained reduction in circulating cholesterol in adult hypopituitary patients given low dose titrated growth hormone replacement therapy: a two year study. Clinical Endocrinology 200053 453-459.

50 Hankinson SE, Willett WC, Colditz GA, Hunter DJ, Michaud DS, Deroo B, Rosner B, Speizer FE \& Pollak M. Circulating concentrations of insulin-like growth factor-I and risk of breast cancer. Lancet 1998351 1393-1396.

51 Chan JM, Stampfer MJ, Giovannucci E, Gann PH, Ma J, Wilkinson P, Hennekens CH \& Pollak M. Plasma insulin-like growth factor-I and prostate cancer risk: a prospective study. Science $1998279563-566$.

52 Giovannucci E, Pollak MN, Platz EA, Willett WC, Stampfer MJ, Majeed N, Colditz GA, Speizer FE \& Hankinson SE. A prospective study of plasma insulin-like growth factor-1 and binding protein-3 and risk of colorectal neoplasia in women. Cancer Epidemiology Biomarkers \& Prevention 20009 345-349.

53 Renehan AG, Zwahlen M, Minder C, O'Dwyer ST, Shalet SM \& Egger M. Insulin-like growth factor (IGF)-I, IGF binding protein-3, and cancer risk: systematic review and meta-regression analysis. Lancet 2004363 1346-1353.

54 Ivan D, Brabant G \& Kann PH. Applicability of recently established reference values for serum insulin-like growth factor 1: a comparison of two assays - an (automated) chemiluminescence immunoassay and an enzyme-linked immunosorbent assay. Clinical Laboratory 200551 381-387.

55 Melmed S. Confusion in clinical laboratory GH and IGF-I reports. Pituitary 19992 171-172.

56 Pokrajac A, Wark G, Ellis AR, Wear J, Wieringa GE \& Trainer PJ. Variation in GH and IGF-I assays limits the applicability of international consensus criteria to local practice. Clinical Endocrinology 200767 65-70.

57 Sherlock M, Aragon Alonso A, Reulen RC, Ayuk J, Clayton RN, Holder G, Sheppard MC, Bates A \& Stewart PM. Monitoring disease activity using growth hormone and insulin like growth factor-I in the follow up of 501 patients with acromegaly. Clinical Endocrinology 2009 71 74-81.

58 Brue T. ACROSTUDY: status update on 469 patients. Hormone Research 200971 34-38.

59 Jenkins PJ, Mukherjee A \& Shalet SM. Does growth hormone cause cancer? Clinical Endocrinology 2006 64 115-121.

Received 19 June 2009

Accepted 24 June 2009 